Jukka Majava, Harri Haapasalo, Kirsi Aaltonen, (2019) "Elaborating factors affecting visual control in a big room", Construction Innovation

This is the author accepted version. The final version of the publication can be found here: https://doi.org/10.1108/CI-06-2018-0048

\title{
Elaborating Factors Affecting Visual Control in a Big Room
}

\begin{abstract}
Purpose - The use of "Big Rooms" and lean philosophy have become increasingly popular in construction. Visual control is a central part of lean philosophy and the Big Room concept; its aim is to improve information flow, joint problem solving and real-time decision making. Visual control facilitates effective project management by providing information on what work is performed and why, customer requirements, deadlines, work status and potential problems. This study explores how visualisation supports project management and control in a Big Room and the factors that facilitate good visual control.
\end{abstract}

Design/methodology/approach - This research is based on the case study method and the objective is to elaborate the current understanding of factors that affect visual control. The study includes a literature review and an empirical study of a large construction project.

Findings - The results indicate that many factors facilitate visual control. Despite the importance of facilities and tools, communication and teamwork are identified as the key factors. On a broader level, the results indicate a need for a holistic approach in developing visual management strategies and practices in the construction industry and in complex projects in particular.

Research limitations/implications - A single case may not be able to offer a generalised picture of this complex topic. However, the study provides novel insights for practitioners and researchers interested in the development of visual control and Big Rooms. Future research topics are also proposed.

Originality/value - While previous studies have identified many elements of successful Big Room implementation-including integration and early involvement, information sharing, tools and facilities - this study focuses specifically on the factors that facilitate visual control.

Keywords - Big Room, Construction industry, Control, Lean philosophy, Visual management

Paper type - Research paper

\section{Introduction}

Annual spending on goods and services in the construction industry is approximately 10 trillion USD. Yet, despite efforts to improve performance and innovation, productivity development in this, one of the world's largest industries, has been poor (Pekuri et al., 2011; Horta et al., 2012; Barbosa et al., 2017). The construction industry has suffered from many issues, such as fragmentation and insufficient standardisation of project management practices. In recent years, a stakeholder-led design process, integration of product and process design, better collaboration and more standardised 
procedures and information have been proposed to address the problems in the industry (Fulford and Standing, 2014; da Rocha and Kemmer, 2018).

A typical construction project includes several stakeholders, such as designers, contractors and subcontractors, in addition to the client. In many cases, the final customer might be unknown or unavailable during the planning and design phases. These stakeholders have their own goals in the project, which can easily lead to sub-optimisation and process waste; that is, non-value-adding activities (Halttula et al., 2017). The project's commercial and contractual structure may also discourage collaboration (Hietajärvi et al., 2017b); therefore, a relational contracting approach called Integrated Project Delivery (IPD) has been proposed as a solution to align the stakeholders' objectives, provide common incentives and facilitate better collaboration between different organisations (Matthews and Howell, 2005; Hietajärvi, 2017a; Rowlinson, 2017).

IPD projects require a co-locational space where stakeholders can work together. Bosch-Sijtsema and Tjell (2017) argue that even though physical space has been neglected in the project literature, it impacts projects in many ways. The "Big Room" concept of co-locational space originally introduced at Toyota (Liker and Morgan, 2006) has become popular in integrated construction projects. The Big Room brings together a project's multiple stakeholders for improved communication and decision making (Dave et al., 2015). Many of the practices applied in the Big Room follow the principles of lean philosophy, which focuses on maximising customer value and minimising non-value-adding activities (Liker, 2004; Melton, 2005).

Visualisation, visual control and visual management are key elements in lean philosophy and in the Big Room concept. Visualisation can be defined as "the representation of an object, situation, or set of information as a chart or other image" (Oxford Dictionaries, 2018). Visual control, in turn, can be seen as a process in which the information is communicated by using visual signals to improve, for example, production and quality control. Visual management, in turn, can be viewed as a comprehensive organisational performance improvement system that provides stakeholders with transparent information on the goals, customers and performance (Liff and Posey, 2004). Successful visualisation enhances information sharing, joint problem solving and real-time decision making. It also supports project management and control, as stakeholders can easily receive visual information on critical control items, such as schedules, quality and costs. Despite the acknowledged role of visual control as a crucial mechanism for improving project coordination and efficiency, further research on the topic is needed in the construction sector (e.g. Tezel et al., 2016). More work is particularly needed on how visual control is actually used in controlling and directing day-to-day project work in colocational environments, such as Big Rooms. Gaining more in-depth understanding of the enablers and actual practice of visual control in complex projects is also important for the development of proper guidelines for visual project management, which is an emerging research area in the field of project management (Williams, 2015).

Consequently, this study focuses on visual management in the Big Room and more specifically on the factors that facilitate visual control in the co-locational space. Accordingly, this paper addresses the following research question: What are the factors that facilitate visual control in a Big Room?

This paper starts with a literature review of the Big Room concept, lean philosophy and visual management to outline the foundation for understanding factors that facilitate visual control in a Big Room. These factors are then analysed in an empirical study. The study explores how managers of a large construction project perceive the factors. The study results are then presented and discussed, and conclusions are drawn.

\section{Literature review}

\section{Big Room}

The Big Room ("Obeya") has its origin in Toyota's product development process where it aimed to enhance cross-functional integration and the focus of product programs (Liker and Morgan, 2006). In construction, the Big Room can be defined as a co-locational space that physically brings together 
different project stakeholders, such as designers, builders and users, to work together (Khanzode and Senescu, 2012). In the construction sector, the concept and brand of the Big Room has been particularly used in integrated project deliveries in the US, although co-locational working spaces are becoming a routine way of integrating construction team members in other types of collaborative projects as well, such as integrated projects (Brady and Davies, 2010) and project alliances (Walker and Lloyd-Walker, 2015). Dave et al. (2015, p. 586) define the Big Room as "a large facility supporting the colocation of the entire project team, where some of the critical problems such as delays in decision making, problems in communication, disparity in design iterations are eliminated, and trust is increased."

Implementations of physical Big Room spaces in construction vary from single rooms to large open offices (Alhava et al., 2015). Although planning the appropriate timing for integrating different stakeholders into a common physical space has proved difficult, prior research has identified many potential benefits that the shared co-locational space may offer. These include, for example, improved collaboration through better team integration, better project results with early stakeholder integration, improved sharing of up-to-date information and reinforced project identity (Khanzode and Senescu, 2012).

Despite its many benefits, the Big Room concept has been criticised. One of the practical critiques of co-locational spaces is the demand for the physical presence of the project participants, which can be highly challenging in geographically distributed projects (Hosseini et al., 2018). Consequently, virtual participation in the Big Room should be enabled (Dave et al., 2015). Khanzode and Senescu (2012) present several recommendations for making a Big Room implementation successful. These focus on technological infrastructure, the planning of the meetings, time management, the prioritisation of issues to be addressed, the use of integrated concurrent engineering (ICE), space planning and the arrangement of people in the space. In addition, Kokkonen and Vaagaasar (2017) particularly emphasise the planning of physical and social space and proper facilitation and leadership to support collaboration in multi-party construction projects. In their explorative study on the role of co-locational space and its use in collaborative projects, Bosch-Sijtsema and Tjell (2017) make empirical observations about the use of Last Planner, one of the most commonly-used tools in Big Room environments. Based on empirical project cases, they conclude that the actual use of Last Planner as a visual tool is relatively limited and relies on the active role of the project manager, while other project participants remain passive receivers of information.

One of the main goals of the Big Room concept is to integrate organisationally-fragmented stakeholders via different integration mechanisms to accomplish a collective set of tasks (Mitropoulos and Tatum, 2000; Hietajärvi et al., 2017a). Mitropoulos and Tatum (2000) propose contractual, organisational and technological integration mechanisms in the design and construction industry. Van de Ven et al. (1976) classify integration mechanisms into three distinct modes: impersonal, personal and group. The impersonal mode of integration is achieved by formalised rules, policies and procedures and by standardised information and communication systems (Van de Ven et al., 1976; Turkulainen et al., 2015). In the personal mode, individuals are the mechanisms for mutual task adjustment through a variety of communication channels (Lawrence and Lorsch, 1967). In the group mode, integration can be achieved by a group of people, such as in cross-unit teams, meetings and integrative departments (Van de Ven et al., 1976; Turkulainen et al., 2015). For example, the Last Planner tool incorporates these mechanisms when applied in project planning, scheduling and control. Last Planner focuses on the joint objectives of the temporary project organisation, luring participants from different permanent organisations to focus on the project and eliminating one of the main problems in multi-stakeholder settings.

\section{Lean philosophy}

Lean philosophy has become popular in various organisations. It includes several methods and ways of developing operations, such as improved production flow, continuous improvement and just-in- 
time (JIT) production (Liker, 2004; Melton, 2005; Rother, 2010; Koch et al., 2012). Typical elements in lean implementation in manufacturing include Kaizen (continuous improvement), standardisation, Kanban cards (pull control), JIT production and the 5S method (Liker, 2004; Melton, 2005; Rother, 2010; Heizer and Render, 2014). The term "lean production system" was introduced in 1988 based on a review of the Toyota Production System (TPS) (Womack et al., 1990). Despite its manufacturing origins, lean principles have also been applied in various other sectors, such as software, healthcare and construction (Landsbergis et al., 1999; Pekuri et al., 2012; Vamsi Krishna Jasti and Kodali, 2014).

Lean construction can be seen as a concept that was derived from the manufacturing industry already over 25 years ago, and various definitions for lean construction can be found in the literature (Marhani et al., 2013). According to Bertelsen (2004, p. 47), lean construction is "to a great extent an adaptation and implementation of the Japanese manufacturing principles within the construction process and in doing this lean construction assumes that construction is a kind of production albeit a special one".

Lean is a long-term philosophy that aims to improve the value stream in a holistic way and to minimise non-value-adding activities (Liker, 2004; Melton, 2005). According to Womack and Jones (1996), the implementation of lean should obey the following principles: define the value produced for the customer, identify value streams and eliminate waste, create a flowing process, implement customer-driven pull control and aim for perfection. Identifying muda (waste) is vital, as the waste generates costs but does not add customer value. Typical waste classes include overproduction, waiting, transport, inventory, overprocessing, motion, defects and unused employee creativity (Melton, 2005; Sternberg et al., 2009). Halttula et al. (2017) examine waste elimination in the construction industry and have found that inadequate communication and documentation, defects and making the wrong products or services are the most severe forms of waste in construction. Halttula et al. (2017) propose Design for Excellence (DfX) and stakeholders' early involvement in waste reduction.

\section{Visual management}

Visual management is a management system that aims to improve organisational performance. It has a long history: The first applications of data visualisation were introduced about 4500 years ago (Tezel et al., 2009). Various definitions exist for visual management in the literature; Brady (2014, p. 27) concludes that visual management can be viewed as "a management strategy for organisational control, measurement and improvement which uses visual aids to externalise information and improve communication in the workplace by creating transparency." Visual management can enhance performance by connecting and aligning the organisational mission, vision, core values, and objectives with other management systems, processes and stakeholders by utilising people's visual sense. Visual management creates an additional dimension to processes, systems and structures; it provides employees with direct access to visual information about an organisation's mission, goals, customers and performance (Liff and Posey, 2004). The benefits include transparent and immediate access to information, which improves information sharing, joint problem solving and real-time decision making. Visual management can serve several functions in organisations, such as transparency, discipline, continuous improvement, job facilitation, on-the-job training, the creation of shared ownership, management by facts, simplification and unification (see Tezel et al., 2009).

The late $19^{\text {th }}$ century started an era of scientific management that introduced tools, such as Gantt charts and process analysis (Heizer and Render, 2014). The use of Gantt charts for the visual control of production began in the 1910s. This was followed by many other graphical tools over the next decades (Tezel, 2009). Visual management is an integral part of development of JIT production, lean philosophy and TPS (Liker, 2004; Tezel, 2009). According to Mann (2010, p. 39), "the status of virtually every process should be visible in lean management". This ensures that employees can immediately see how processes actually work and if there are deviations from the plans and expectations. A visual work environment should provide the answers to the following questions: what 
work is being done, why, when it should be ready, what problems and questions exist, if the customers are happy and the status of the work (Kattman et al., 2012). A number of things, such as the schedule, the budget, collaboration, defects and reworks can be visualised. Avoiding sub-optimisation should be considered the goal in choosing the factors that are visually monitored.

Visual management includes a variety of tools that can be applied in daily operations, quality control and the management of work stations, offices and organisations. The tools include, for example, tracking charts, colour coding, priority charts, Heijunka (completion) charts, Kanban, Andon lights, call lights, display panels, visual controls in poka-yoke, work schedules, bordering and recoil (Mann, 2010; Kattman et al., 2012). Regarding quality control, Kaoru Ishikawa claims that most problems can be resolved with seven basic visual tools: flowcharts, Pareto diagrams, check sheets, cause and effect diagrams, histograms, scatter diagrams and control charts (Tezel et al., 2009). Visual management elements can also be found in statistical process control (SPC), a quality control method for process monitoring and control. SPC methods include run charts, control charts, a process capability index, a focus on continuous improvement and the design of experiments. SPC aims to present a compressed and visual view of processes from a large amount of information. With more advanced SPC methods, the development of a process can be forecasted to prevent potential problems for quality assurance (QA) purposes (Wheeler, 1995; Dale, 2000).

\section{Synthesis of the factors that facilitate visual control in Big Rooms}

The literature review findings are synthesised in Table 1 below. To identify the factors that facilitate visual control in a Big Room, three inter-related viewpoints must be considered: the context, the approach and the methods that affect visual control in a Big Room.

Table 1. Synthesis of the factors that facilitate visual control in Big Rooms

\begin{tabular}{|c|c|c|}
\hline Viewpoint & Factor & Description \\
\hline \multirow{3}{*}{$\begin{array}{l}\text { Big Room } \\
\text { context }\end{array}$} & Facilities & Big Room space \\
\hline & $\begin{array}{l}\text { Planning of activities, } \\
\text { rules and responsibilities }\end{array}$ & $\begin{array}{l}\text { Planned and agreed-on practices } \\
\text { for cooperation }\end{array}$ \\
\hline & Facilitators & $\begin{array}{l}\text { People supporting teamwork } \\
\text { (e.g. integration coordinator) }\end{array}$ \\
\hline \multirow{3}{*}{$\begin{array}{l}\text { Lean } \\
\text { approach }\end{array}$} & Teamwork & $\begin{array}{l}\text { Cooperation involving respect } \\
\text { and integrity (to decrease waste) }\end{array}$ \\
\hline & $\begin{array}{l}\text { Concurrent engineering } \\
\text { and early involvement }\end{array}$ & $\begin{array}{l}\text { Concurrent problem solving and } \\
\text { involving stakeholders early }\end{array}$ \\
\hline & $\begin{array}{l}\text { Systemisation and } \\
\text { continuous improvement }\end{array}$ & $\begin{array}{l}\text { Systematic way of work and } \\
\text { finding improvements } \\
\text { constantly }\end{array}$ \\
\hline \multirow[t]{2}{*}{$\begin{array}{l}\text { Visual } \\
\text { methods }\end{array}$} & $\begin{array}{l}\text { Communication and } \\
\text { information sharing }\end{array}$ & $\begin{array}{l}\text { Creation of joint understanding } \\
\text { of objectives and operations } \\
\text { among project participants }\end{array}$ \\
\hline & Tools & Tools and technical solutions \\
\hline
\end{tabular}

The Big Room provides a context that emphasises the role of physical space (facilities) and the planning of activities, rules and responsibilities. The physical space alone is not important, but it enables people from different permanent organisations to join a temporary organisation - that is, the project. Through the physical space, people can participate in open interaction and communication with each other (Dave et al., 2015). In addition, the role of facilitators is important in the Big Room (Khanzode and Senescu, 2012). In particular, at the beginning of the project the utilisation of the Big 
Room necessitates adopting new roles and responsibilities; for example, integrative activities (Hietajärvi et al., 2017a) and project data models require special attention and focus. Later, these should be part of the "normal responsibilities" of the project manager to ensure effective and efficient project administration.

Regarding the approach, adopting lean philosophy calls for teamwork, concurrent engineering, early involvement and systemisation, and continuous improvement. Visual management, in turn, provides methods that focus on improving communication and information sharing using a variety of tools. All these factors relating to the context, approach and methods can be considered important for facilitating visual control in the Big Room.

\section{Research process}

This research is based on the case study method (Yin, 2009). The research is qualitative in nature, and the objective is to elaborate the current body of knowledge. The study started with a literature review to identify the factors of visual control in Big Rooms. Next, an empirical study was planned and a questionnaire created to support data collection from the informants. The questionnaire included the following factors of visual control: communication and information sharing; teamwork; planning of activities, rules and responsibilities; systemisation and continuous improvement; facilities; concurrent engineering and early involvement; facilitators; and tools.

The rationale for utilising a single case was the opportunity to gain in-depth insights; several examples have shown that many important studies that have advanced knowledge are based on a single case (Dyer and Wilkins, 1991; Siggelkow, 2007). The empirical case under study is a large construction project that was at the end of the planning phase during the data collection. The case was selected for the study due to its size and complexity, which increased the importance of visual control in the project. The objective of the project is to create a new transportation system in a city in Southern Finland. The total budget of the project is approximately three hundred million euros. The project phases include forming the alliance, the planning phase, the construction phase and the maintenance phase. The project planning phase was carried out in 2015 and 2016. The cost of the planning phase was approximately 10 million euros. During the planning phase, the project alliance created a detailed implementation plan and defined the target cost for the project. In addition, the planning phase included zoning, street planning-related and permit process-related tasks. The first phase of the construction work started in 2017 and it is planned to be finished in 2021. The project alliance includes four main parties: the city as the customer, and three private companies responsible for the design and the construction work. The project building site is divided into five sections, and a joint Big Room space also exists. The people who work on the project are located in several different places, which necessitates effective information sharing. In total, eleven informants representing four different organisations participated in the study (Table 2). The informants were part of the Big Room.

Table 2. Study participants

\begin{tabular}{llll}
\hline Informant & Organisation type & Role & $\begin{array}{l}\text { Industry } \\
\text { experience (years) }\end{array}$ \\
\hline 1 & $\begin{array}{l}\text { Construction company } \\
\text { Consulting and } \\
\text { engineering company }\end{array}$ & Construction manager & 27 \\
2 & $\begin{array}{l}\text { Infrastructure design, } \\
\text { construction and } \\
\text { maintenance company }\end{array}$ & $\begin{array}{l}\text { Bid manager, responsible } \\
\text { for the budget }\end{array}$ & 13 \\
3 & $\begin{array}{l}\text { Infrastructure design, } \\
\text { construction and } \\
\text { maintenance company }\end{array}$ & $\begin{array}{l}\text { Street and tramrail } \\
\text { planner }\end{array}$ & 10 \\
4 & & &
\end{tabular}


5

6

7

8

9

10

11
Construction company

Infrastructure design,

construction and

maintenance company

Infrastructure design,

construction and

maintenance company

Infrastructure design,

construction and

maintenance company

Infrastructure design,

construction and

maintenance company

Consulting and

engineering company

Municipality
Project engineer (cost

management and control)

Information model

coordinator

Tramrail superstructure

technical chief

Group manager, product

development manager

Project engineer

10

Tramrail technical design

chief

Urban planning manager 18

The participants were selected in cooperation with the key project stakeholders. A data collection workshop was organised, during which the participants provided their views on the importance of different factors of visual control by filling in the data collection questionnaire that included factors that facilitate visual control in Big Rooms (Table 1). After the written evaluation of each factor, there was a group discussion between the researcher and workshop participants. The purpose of the discussion was to clarify why the factor was important and what type of requirements are related to it. The workshop discussions were recorded. The data analysis was conducted by using a qualitative approach (Eisenhardt, 1989). The workshop notes, questionnaire answers and recordings were analysed to find emerging connections and patterns related to factors that affect visual control. The observations were structured into more generic categories to identify the key concepts and issues. Finally, the results were presented to the study participants to get feedback and validate the findings.

\section{Results}

The importance of factors that facilitate visual control

Table 3 presents the mean scores of different factors given by the study participants.

Table 3. Mean scores for factors that facilitate visual control

\begin{tabular}{ll}
\hline Factor & Importance* \\
\hline Communication and information sharing & 4.70 \\
Teamwork & 4.56 \\
Planning of activities, rules and responsibilities & 4.40 \\
Systemisation and continuous improvement & 4.22 \\
Facilities & 4.00 \\
Concurrent engineering and early involvement & 4.00 \\
Facilitators & 3.78 \\
Tools & 3.70 \\
*scale: $1=$ not important, 2 = somewhat important, 3 & reasonably important, \\
4=important, and 5 = very important & \\
\hline
\end{tabular}


As Table 3 illustrates, communication and information sharing was considered the most important factor for visual control according to the study participants. Seven informants saw that communication and information sharing is very important, and three participants considered it important. Teamwork and the planning of activities, rules and responsibilities were both considered almost equally as important as communication and information sharing; six informants saw them as very important, and two informants considered them important. Systemisation and continuous improvement was seen as very important by three participants, and as important by five participants. Finally, it should be noted that all the participants saw each factor to be at least reasonably important, which demonstrates the relevance of each factor included in the study.

\section{Insights into the factors that facilitate visual control}

Several interesting insights related to each factor were discovered. Regarding communication and information sharing, the importance of common, interoperable systems and platforms was emphasised in the research results. The informants saw that information sharing practices should be clear and that plans and decisions should be visible for everyone (i.e. creating transparency), including those participating in the Big Room from a remote location. The key items that were thought necessary to visualise in the Big Room were a map that provides an overview of the project, a schedule and a more informal status overview (i.e. "how we are doing at the moment"). The participants also suggested acquiring a large touch display with links to videos, documents and the design database. For successful communication and information sharing, people were expected to have the ability to learn and absorb new information; to be active, social and interactive; and to be able to communicate and listen. Openness and cooperativeness were also deemed important by the participants. In addition, one generic issue related to information sharing was raised; as several people external to the project visit the Big Room, having separate name tags for project participants and visitors was considered important. The Big Room is open in nature, but not all the information can be shared with external visitors.

Teamwork includes several aspects, such as trust, credibility, openness, sincerity and attitudes. Successful teamwork was also considered in terms of visual control. It requires an open database and a physical space that is suitable for joint working and that is flexible in terms of being transformed for different uses. The space should make it easy to approach people and have basic technological capabilities in place, such as a good internet connection. However, successful teamwork also sets certain requirements in terms of the people involved in the project. These include keeping promises, sincerity, contributing and committing to teamwork, the ability to cooperate, taking others into account, respecting diversity and joint rules, "personal chemistry", trust, and openness.

The study participants saw that planning of activities, rules and responsibilities necessitates that the guidelines are visible, clear and understandable and that the most important rules should be highly visible. People were expected to follow the guidelines and be responsible and committed to the joint rules. Moreover, responsibility-sharing and organising should be paid attention to. The rules should be jointly developed and rehearsed on a frequent basis.

Systemisation and continuous improvement was also considered an important factor that facilitates visual control. In order to succeed in this area, appropriate space and equipment are needed. The space should include visual information boards connected to common systems, and it should be possible to easily adapt the space to different needs. People are required to have the ability and willingness to learn and develop themselves and to adopt new practices. The management should monitor the activities and encourage people in their work.

Regarding facilities (i.e. the physical Big Room space), the study participants stressed that location, accessibility, versatility and a large environment with enough wall space for presenting visual information are required. Overall, it was also highlighted that to be able to work successfully in a Big 
Room, the people should be able to adapt and be flexible, be capable of focusing, provide a peaceful working environment for everyone and be committed to be present in the Big Room.

Concurrent engineering and early involvement were considered to require a common database, a visual information model and a communication channel. In addition, it was seen as important that external stakeholders have access to the documentation, that the information is up-to-date and that the technical systems and applications are working well. Furthermore, people should be genuinely interested in others' activities, willing to help others and share information with the identified stakeholders. People should also be good at interacting and communicating and should have the courage to share drafts and plans that are still in progress.

Facilitators have a key role in promoting visual control in the Big Room. To succeed in their role, the facilitators must have appropriate visual tools and utilities, such as flip charts and Post-it notes, and the physical spaces should support working in groups. The facilitators are required to possess good facilitation skills and should have a clear understanding of the project status and goals. However, these things are not enough. The facilitators should also be able to communicate the goals well, be well-prepared and be able to inspire and encourage others. The people who are development-oriented and good at communicating and organising were considered to have the best chances to succeed as facilitators. However, it was also emphasised that everyone's commitment is needed in the project.

Finally, with regard to tools, the study results highlight the importance of network connections, visual walls and boards, virtual and digital connectivity, powerful computers and the use of a single storage space to avoid entering the same data multiple times. People should be able to learn and adopt new things; support and guidance for tools should be available; and people should commit to learn and use the agreed-upon tools and methods.

\section{Discussion}

Visual management that utilises visual tools and visualisation methodologies is an increasingly used means to support the control and management of complex construction projects. The crucial role of visual elements in facilitating information sharing and communication across individuals and organisations in co-locational working spaces such as Big Rooms has been acknowledged in prior literature (Kokkonen and Vaagaasar, 2017). Despite its acknowledged practical relevance and potential in communicating project-based and accurate information to various stakeholders, only few studies to date (Tezel et al., 2016; Williams, 2015) have addressed the factors and elements that actually facilitate proper visual control in the context of a multi-organisational co-locational space. The findings of this study on these factors contribute to the emerging research stream on visual project management and help us in building a more comprehensive and in-depth understanding and portrayal of the multi-dimensional concept of visual project management and how it can be practiced successfully in co-locational projects.

The results of the study revealed that diverse factors facilitate visual control in Big Rooms. The findings suggest that visual management is by no means primarily a technical issue of selecting the right visual tools, but that its proper use and benefits may only realise when more attention is paid to social processes inherent in project management, such as communication and information sharing and teamwork, which were identified as the most important factors that facilitate visual control. Consequently, the findings imply that investing early and adequately in the socialisation processes within the project team and in the co-locational space is therefore highly relevant for the success of visual management in complex projects. Halttula et al. (2017) noted that the biggest waste in fragmented construction projects is poor communication and information sharing, especially between participants and people. To remove this waste, visual control is in a key role for improving efficiency and making information available and easy to adapt. These findings add a novel and interesting perspective for the prior studies on visual management that have rarely discussed the role of socialisation in facilitating visual control (Aaltonen and Turkulainen, 2018), but instead have adopted a more tool-oriented perspective (Tezel et al., 2016). This opens up the greatest and most difficult 
potential in improvement: how people operate and learn. More research is, however, needed on the reinforcing cycle of visual control, as its use may also reinforce and strengthen the socialisation processes in complex projects.

In addition, the findings stress the demand for more formal and systematic practices, such as clear rules, the utilisation of a common database and the continuous development of visualisation by using, for example, maps. Such practices are vital in implementing and rooting the practices of visual management in the daily Big Room activities. In addition, the role of the co-location physical space and its organisation is central in facilitating proper visual control. The findings of the study, hence, also contribute to the research stream that is starting to take space and its role in guiding and enabling project management processes seriously (Bosch-Sijtsema and Tjell, 2017). Finally, the results of the study suggest that skilful facilitators are central in enabling successful visual control. Prior literature has paid only limited attention to the roles that facilitators may adopt in guiding visual project management processes (Karrbom Gustavsson, 2015).

Overall, the findings that highlight various factors that facilitate visual control strongly imply that visual management in the project may need a strategy of its own that should be crafted and implemented relatively early during the project life-cycle. Overall, it should be assessed in the future by scholars and practitioners whether visual management plans, defined processes and strategy for the visual project management process as novel managerial knowledge areas are something that should be incorporated into the formal project management standards and knowledge areas (PMI, 2013), as well as into the management of complex projects. The challenge in coordinating complex, networked projects with a multicity of organisations is to ensure that proper knowledge is with the right person at the right time. This is a remarkable challenge in the context of complex, changing and interdependent tasks. Visual control, and visual project management overall, may offer a simple avenue and "simple rules" (Sull and Eisenhardt, 2015) particularly for the management of complex projects. This study also broadens our understanding of this area, as the role of visual management in coordination trajectories in complex projects is an area that has been only limitedly discussed in prior literature (Bosch-Sijtsema and Tjell, 2017; Hietajärvi et al., 2017a).

\section{Managerial implications}

Overall, the study's participants had positive experiences of the Big Room concept during the project. Nevertheless, some concrete development items were also identified. The short-term development needs included making the joint decisions more visible, adding more displays for improving information sharing, enhancing visitor guidance and identification in the Big Room, gathering feedback on job satisfaction (smiley rating polls) on a weekly basis and providing more visibility for the most important joint rules.

For successful visual management in Big Room construction projects, practitioners should consider the following issues based on the findings of this study. First, the teamwork prerequisites (e.g. trust) should be focused on and built consciously from the beginning of the project, particularly when the project shifts from the design phase to the implementation phase. Second, effective communication and information sharing should be enabled. Concrete examples of organising these things could include the following. When the project starts or enters a new phase that involves new stakeholders, an induction day should be organised for all the project participants, including remote team members. During the day, people can become familiar with each other, work on team-building and agree on the joint goals and rules in the project. Finally, it is also vital to have a common database and people's commitment to use it as agreed on (including the database structure, naming of files, etc.). The plans, decisions and a log file of decisions should be made visible and easily accessible for the project participants. The construction industry could also benefit from benchmarking other industries. For example, using war rooms in complex IT system implementations could provide a useful benchmark. 


\section{Limitations and further research}

It should be noted that this study focused on the project's design phase. In the implementation phase, several new stakeholders will become involved, which requires the investment of sufficient time and effort in socialisation and team building for the new participants. Further research is particularly needed on the enactment of visual project management during this stage. In addition, the role of virtual connections to the Big Room becomes an important factor, as many participants may not be physically present in the co-locational space. Further research efforts are needed on the good practices in implementing visual management in distributed and virtual teams.

\section{Conclusions}

This paper explored visual control in construction. In particular, the study presented in this paper focused on the factors that facilitate visual control in a large, complex construction project that utilised the Big Room concept. The results of this study indicate that several factors facilitate visual control. While many factors were identified as important, the most central factors were communication and information sharing and teamwork. These factors are essential in reducing waste in complex construction projects. Therefore, we recommend that practitioners focus on these factors, especially at the beginning of a project and when the project enters a new phase involving new stakeholders.

Overall, the results of this study are in line with those of previous studies (e.g. Tezel et al., 2016) in that they indicate an obvious need for developing visual management in the construction industry and in complex projects in particular. Furthermore, a holistic approach to visual control in the projects is needed instead of focusing solely on individual visual tools and their implementation.

It should be noted, however, that our findings are based on a single case study. It is recommended that in addition to addressing this limitation, future research should include topics such as how the benefits of visual management could be provided to stakeholders who participate in the Big Room remotely.

\section{References}

Aaltonen, K., Turkulainen, V. (2018), "Creating relational capital through socialization in project alliances", International Journal of Operations \& Production Management, Vol. 8, No. 6, pp. $1378-1421$.

Alhava, O., Laine, E. and Kiviniemi, A. (2015), "Intensive big room process for co-creating value in legacy construction projects", Journal of Information Technology in Construction (ITcon), Vol. 20, No. 11, pp. 146-158.

Barbosa, F., Woetzel, J., Mischke, J., Joao Ribeirinho, M., Sridhar, M., Parsons, M., Bertram, N. and Brown, S. (2017), "Reinventing construction through a productivity revolution", McKinsey Global Institute, available at: https://www.mckinsey.com/industries/capital-projects-andinfrastructure/our-insights/reinventing-construction-through-a-productivity-revolution (accessed 6 June 2018).

Bertelsen, S. (2004), "Lean Construction: Where are we and how to proceed", Lean Construction Journal, Vol. 1, No, 1, pp. 46-69.

Bosch-Sijtsema, P. M. and Tjell, J. (2017), "The concept of project space: Studying construction project teams from a spatial perspective", International Journal of Project Management, Vol. 35 No. 7, pp. 1312-1321.

Brady, D. A. (2014), Using visual management to improve transparency in planning and control in construction, Doctoral dissertation, University of Salford, Salford, UK.

Brady, T. and Davies, A. (2010), "Learning to deliver a mega-project: The case of Heathrow terminal 5", in Caldwell, N. and Howard, M. (Eds.), Procuring Complex Performance: Studies of Innovation in Product-Service Management, Routledge, New York, NY, pp. 74-198.

Dale, B. G. (2000), Managing Quality, 3rd ed., Blackwell Ltd, Oxford, UK. 
da Rocha, C. G. and Kemmer, S. (2018), "Integrating product and process design in construction", Construction Management and Economics.

Dave, B., Pikas, E., Kerosuo, H., and Mäki, T. (2015), "ViBR-conceptualising a virtual big room through the framework of people, processes and technology", Procedia Economics and Finance, Vol. 21, pp. 586-593.

Dyer, W. G. and Wilkins A.L. (1991), "Better stories, not better constructs, to generate better theory: A rejoinder to Eisenhardt", Academy of Management Review, Vol. 16, No. 3, pp. 613-619.

Eisenhardt, K.M. (1989), "Building theories from case study research", Academy of Management Review, Vol. 14, No. 4, pp. 532-550.

Fulford, R. and Standing, C. (2014), "Construction industry productivity and the potential for collaborative practice", International Journal of Project Management, Vol. 32, No. 2, pp. 315326.

Halttula, H., Haapasalo, H., Aapaoja, A. and Manninen, S. (2017), "Early involvement and integration in construction projects: the benefits of DfX in elimination of wastes", International Journal of Management, Knowledge and Learning, Vol. 6, No. 2, pp. 215-237.

Heizer J. and Render B. (2014), Operations Management: Sustainability and Supply Chain Management, Pearson education Ltd., USA.

Hietajärvi, A. M., Aaltonen, K. and Haapasalo, H. (2017a), "Managing integration in infrastructure alliance projects: Dynamics of integration mechanisms", International Journal of Managing Projects in Business, Vo. 10, No. 1, pp. 5-31.

Hietajärvi, A. M., Aaltonen, K. and Haapasalo, H. (2017b), "Opportunity management in large projects: A case study of an infrastructure alliance project”, Construction Innovation, Vol. 17, No. 3, pp. 340-362.

Horta, I. M., Camanho, A. S. and Da Costa, J. M. (2012), "Performance assessment of construction companies: A study of factors promoting financial soundness and innovation in the industry", International Journal of Production Economics, Vol. 137, No. 1, pp. 84-93.

Hosseini, M. R., Bosch-Sijtsema, P., Arashpour, M., Chileshe, N. and Merschbrock, C. (2018), “A qualitative investigation of perceived impacts of virtuality on effectiveness of hybrid construction project teams", Construction Innovation, Vol. 18, No. 1, pp. 109-131.

Karrbom Gustavsson, T. (2015), "New boundary spanners: Emerging management roles in collaborative construction projects", Procedia Economics and Finance, Vol. 21, pp. 146-153.

Kattman, B., Corbin, T. P., Moore, L. E. and Walsh, L. (2012), "Visual workplace practices positively impact business processes", Benchmarking: An International Journal, Vol. 19, No. 3, pp. 412-430.

Khanzode, A. and Senescu, R. (2012), "Making the integrated Big Room better", DPR Construction, available at: https://www.dpr.com/view/making-big-room-better (accessed 6 June 2018).

Koch T., Horbal R., Kagan R., Sobczyk T. and Plebanek S. (2012), "10 commandments for the boss of a company implementing Lean philosophy", Management and Production Engineering Review, Vol. 3, No. 2, pp. 62-78.

Kokkonen, A. and Vaagaasar, A. L. (2017), "Managing collaborative space in multi-partner projects", Construction Management and Economics, Vol. 36, No. 2, pp. 83-95.

Landsbergis P. A., Cahill J. and Schnall P. (1999), "The impact of lean production and related new systems of work organization on worker health", Journal of Occupational Health Psychology, Vol. 4, No. 2, pp. 108-130.

Lawrence, P. R. and Lorsch, J. W. (1967), "Differentiation and integration in complex organizations", Administrative science quarterly, pp. 1-47.

Liff, S. and Posey, P. A. (2004), Seeing Is Believing: How the New Art of Visual Management Can Boost Performance throughout Your Organization, AMACOM, New York, NY.

Liker J.K. (2004), The Toyota Way: 14 Management Principles from the World's Greatest Manufacturer, McGraw-Hill, New York, NY. 
Liker, J. K. and Morgan, J. M. (2006), "The Toyota way in services: the case of lean product development", The Academy of Management Perspectives, Vol. 20, No. 2, pp. 5-20.

Mann, D. (2010), Creating a Lean Culture: Tools to Sustain Lean Conversions, CRC Press, New York, NY.

Marhani, M. A., Jaapar, A., Bari, N. A. A. and Zawawi, M. (2013), "Sustainability through lean construction approach: A literature review", Procedia-Social and Behavioral Sciences, Vol. 101, pp. 90-99.

Matthews, O. and Howell, G. A. (2005), "Integrated project delivery an example of relational contracting", Lean Construction Journal, Vol. 2, No. 1, pp. 46-61.

Melton T. (2005), "The benefits of lean manufacturing: what lean thinking has to offer the process industries", Chemical Engineering Research and Design, Vol. 83, No. 6, pp. 662-673.

Mitropoulos, P. and Tatum, C. B. (2000), "Management-driven integration", Journal of Management in Engineering, Vol. 16, No. 1, pp. 48-58.

Oxford Dictionaries. (2018), "Visualization", Oxford Dictionaries, available at: https://en.oxforddictionaries.com/definition/visualization (accessed 23 July 2018).

Pekuri, A., Haapasalo, H. and Herrala, M. (2011), "Productivity and performance managementmanagerial practices in the construction industry", International Journal of Performance Measurement, Vol. 1, No. 1, pp. 39-58.

Pekuri A., Herrala M., Aapaoja A. and Haapasalo H. (2012), "Applying Lean in constructioncornerstones for implementation", in Proceedings of the 20th Annual Conference of the International Group for Lean Construction.

Project Management Institute. (2013), A guide to the project management book of knowledge (PMBOK). Newtown Square, PA.

Rother M. (2010), Toyota Kata: Managing People for Improvement, Adaptiveness and Superior Results, McGraw-Hill, USA.

Rowlinson, S. (2017), "Building information modelling, integrated project delivery and all that", Construction Innovation, Vol. 17, No. 1, pp. 45-49.

Siggelkow, N. (2007), "Persuasion with case studies", Academy of Management Journal, Vol. 50, No. 1, pp. 20-24.

Sternberg H., Stefansson G., Westernberg E., Boije af Gennäs R., Allenström E. and Linger Nauska M. (2009), "Applying a lean approach to identify waste in motor carrier operations", International Journal of Productivity and Performance Management, Vol. 62, No. 1, pp. 47-65.

Sull, D. and Eisenhardt, K. (2015), Simple rules: How to thrive in a complex world, Houghton Mifflin Harcourt Publishing Company, New York.

Tezel, A., Koskela, L. J. and Tzortzopoulos, P. (2009), “The functions of visual management”, in International Research Symposium, Salford, UK.

Tezel, A., Aziz, Z., Koskela, L. and Tzortzopoulos, P. (2016), "Visual management condition in highways construction projects in England", in Proceedings of the 24th Annual Conference of the International Group for Lean Construction, Boston, MA, USA, sect. 6, pp. 133-142.

Turkulainen, V., Ruuska, I., Brady, T. and Artto, K. (2015), "Managing project-to-project and project-to-organization interfaces in programs: Organizational integration in a global operations expansion program", International Journal of Project Management, Vol. 33, No. 4, pp. 816-827.

Vamsi Krishna Jasti N. and Kodali R. (2014), "A literature review of empirical research methodology in lean manufacturing”, International Journal of Operations \& Production Management, Vol. 34, No. 8, pp. 1080-1122.

Van de Ven, A. H., Delbecq, A. L. and Koenig Jr, R. (1976), "Determinants of coordination modes within organizations", American Sociological Review, pp. 322-338.

Walker, D.H.T. and Lloyd-Walker, B.M. (2015), Collaborative Project Procurement Arrangements, Project Management Institute, Newtown Square, PA.

Wheeler, D. J. (1995), Advanced Topics in Statistical Process Control, SPC press, Knoxville, TN. 
Williams, P. R. (2015), "Visual project management”, Paper presented at PMI ${ }^{\circledR}$ Global Congress 2015-EMEA, London, England. Project Management Institute, Newtown Square, PA.

Womack J.P. and Jones D.T. (1996), Lean Thinking: Banish Waste and Create Wealth in Your Corporation, Simon \& Schuster, New York, NY.

Womack J.P., Jones D.T. and Roos D. (1990), The Machine That Changed the World, Rawson Associates, New York, NY.

Yin, R.K. (2009), Case Study Research: Design and Methods, Sage Publications, Los Angeles, CA. 